J. Clin. Chem. Clin. Biochem.

Vol. 14, 1976, pp. 533-535

\title{
Separation of Arginase Isoenzymes from Human Tissues by Agar Gel Electrophoresis
}

\author{
By Olga Borčić and B. Šstraus
}

Institute of Medical Biochemistry, Faculty of Pharmacy and Biochemistry, University of Zagreb, Yugoslavia

(Received December 19, 1975/June 15, 1976)

Summary: Arginase (EC 3.5.3.1) from human liver, kidney, mammary gland, and erythrocytes, was separated by agar-gel electrophoresis using barbital buffer $\mathrm{pH}$ 8.6. Three isoenzymes were separated. Two of these, $A_{2}$ and $A_{3}$, occur in liver and erythrocytes. The same two isoenzymes were found in the kidney, but in reversed proportions. In addition to the $A_{3}$ isoenzyme, the mammary gland contains a fast anodically moving $A_{1}$ isoenzyme. The three isoenzymes differ in their degree of sensitivity to ornithine.

\section{Elektrophoretische Trennung der Arginase-Isoenzyme aus Geweben des Menschen durch Agargelelektrophorese}

Zusammenfassung: Arginase (EC 3.5.3.1) aus menschlicher Leber, Niere, Brustdrüsen und Erythrocyten wurde elektrophoretisch in Agargel getrennt. Drei Isoenzyme wurden gefunden. Zwei von ihnen, $A_{2}$ und $A_{3}$, kommen in Leber und Erythrocyten vor. Die selben Isoenzyme befinden sich auch in der Niere, aber in umgekehrtem Verhältnis. Neben dem $A_{3}$-Isoenzym befindet sich in der Brustdrüse ein rasch anodisch wanderndes $A_{1}$-Isoenzym. Ornithin hemmt die Aktivität der drei Isoenzyme verschieden stark.

\section{Introduction}

Differences among arginases ( $L$-arginine amidinohydrolase, EC 3.5.3.1) from various tissues were noted a long time ago when it was shown that the conditions for measuring arginase activity in one tissue were not equally suitable for arginase tests in another tissue (1). Differences in the $\mathrm{pH}$ activity curves (2) and immunochemical properties were also noted (3). Using electrophoretic (4) and chromatographic techniques two isoenzymes of the mammary gland have been found $(4,5,6)$, while the results concerning the number of liver and erythrocyte arginase isoenzymes are not consistent $(4,5,6,7,8)$. This paper deals with the technique set up in our laboratory for the separation of arginase isoenzymes and with the results obtained with arginase from various human tissues.

\section{Material and Methods}

Tissues were obtained within six hours post mortem. They were washed with saline, freed of connective tissue and of fat which is particularly abundant in the mammary gland. Portions of $0.2 \mathrm{~g}$ of tissue were homogenized in a Potter Elvehjem homogenizer in $1 \mathrm{ml}$ of $5 \mathrm{~g} / 1$ Triton $\mathrm{X}-100$ in $0.5 \mathrm{mmol} / 1 \mathrm{MnCl}_{2}$ solution. The homogenates were centrifuged at $14,000 \mathrm{~g}$ for 20 minutes the supernatants lyophilised and kept dry at $+4^{\circ} \mathrm{C}$ until tested. Prior to the analysis they were dissolved in water to give solutions equivalent to $0.15 \mathrm{mg}$ of fresh liver tissue, and $2-3 \mathrm{mg}$ of kidney or mammary gland tíssue per ml. Hemoly sates were prepared by freezing and thawing of erythrocytes which had been separated from plasma and washed three times with saline. Total arginase activity in tissues and hemolysates was determined by the method described by Jergovic et al (9), but with a shorter incubation time. Activity is expressed as U/g of fresh tissue or, in the case of hemolysates, per gram of hemoglobin. Electrophoresis was performed on microscope slides in $10 \mathrm{~g} / 1$ Difco Noble agar (10) dissolved in barbital buffer, $\mathrm{pH} 8.6$, ionic strength 0.02 at $7 \mathrm{~V} / \mathrm{cm}$, for 120 minutes. The isoenzymes were located in two ways, by ornithine and by the urea formed in the enzyme reaction.

For the localisation of arginase activity in the gel with ornithine we developed a method based on the reaction of ornithine with ninhydrin in acidic medium $(11,12)$. When electrophoretic run was finished the gel was covered with Whatman No. 1 filter paper, impregnated with a solution of arginine and activator of the same concentrations, as in the determination of total activity. This sand wich was incubated at $37^{\circ} \mathrm{C}$ for 30 minutes, the paper stripped off, dried, dipped for a moment in a $50 \mathrm{~g} / \mathrm{l}$ solution of ninhydrin in equals parts of acetone and propanol, left at room temperature until the colour appeared and then sprayed with a $500 \mathrm{~g} / \mathrm{l}$ solution of trichloracetic acid in acetone. Faint red spots thus obtained indicated the positions of arginase activities.

For the quantitative determination of isoenzymes with urea the gel was cut into $5 \mathrm{~mm}$ wide segments and each segment was transferred to a test tube containing $1 \mathrm{ml}$ of distilled water, and arginase activity was determined in the same way as for the total activity. To test the inhibitory effect of $L$-ornithine on the electrophoretically separated isoenzymes, $L$-ornithine was added to the reaction mixtures in the concentration of $77 \mu \mathrm{mol} / \mathrm{l}$, equimolar with arginine.

\section{Results}

The electrophoresis of liver, erythrocyte, kidney and mammary gland arginase yielded three different isoenzymes that we designated $A_{1}, A_{2}$ and $A_{3}$. Two of 
them exist in each of the tissues examined. Figure 1 shows the electrophoretic pattern obtained by the elution of gel strips (A) and by ninhydrin reaction (B).

The liver arginase is composed of two isoenzymes. $A_{3}$, which accounts for roughly $90 \%$ of the total activity, moves towards the cathode and the weaker, $A_{2}$, is carried towards the anode. In the kidney extract pherogram the same two isoenzymes are visible but in reversed proportions. Two arginase isoenzymes could also be demonstrated in the mammary gland extracts. One contained a smaller fraction of the total activity corresponding to the cathodic $A_{3}$ isoenzyme, the same as in the liver and kidney, while a much stronger anodic isoenzyme $A_{1}$ was found only in the mammary gland. The same two isoenzymes, in the same proportions, are present in the erythrocytes as in the liver. However, the hemoglobin spot hindered the development of the ninhidrin reaction of ornithine at the site of $\mathrm{A}_{2}$ isoenzyme, and thus it could be located only by urea determination of the appropriate segment. The percentage distribution of the isoenzymes is sinown in table 1.

Tab. 1. Arginase activities and isoenzymes distribution.

\begin{tabular}{|c|c|c|c|c|c|}
\hline$n=8$ & & $\begin{array}{l}\text { Total } \\
\text { activity } \\
\left.\mathrm{U} / \mathrm{g}^{1}\right)\end{array}$ & $\begin{array}{l}\text { Isoen } \\
\mathrm{A}_{3} \\
\%\end{array}$ & $\begin{array}{l}\mathrm{A}_{2} \\
\%\end{array}$ & $\begin{array}{l}A_{1} \\
\%\end{array}$ \\
\hline Ljver & $\begin{array}{l}\bar{x} \\
s \\
\text { CV\% }\end{array}$ & $\begin{array}{r}418 \\
89 \\
21.3\end{array}$ & $\begin{array}{r}89.6 \\
2.8 \\
3.1\end{array}$ & $\begin{array}{c}10.4 \\
2.1 \\
20\end{array}$ & $\begin{array}{l}- \\
-\end{array}$ \\
\hline $\begin{array}{l}\text { Erythro- } \\
\text { cytes }\end{array}$ & $\begin{array}{l}\bar{x} \\
s \\
\text { CV\% }\end{array}$ & $\begin{array}{c}42.9 \\
6.0 \\
14\end{array}$ & $\begin{array}{r}91.6 \\
2.4 \\
2.6\end{array}$ & $\begin{array}{c}8.4 \\
2.8 \\
33\end{array}$ & $\begin{array}{l}- \\
-\end{array}$ \\
\hline Kidney & $\begin{array}{l}\bar{x} \\
s \\
\text { CV\% }\end{array}$ & $\begin{array}{r}8.8 \\
1.8 \\
20.4\end{array}$ & $\begin{array}{r}18.6 \\
4.2 \\
22.6\end{array}$ & $\begin{array}{r}81.4 \\
4.6 \\
5.6\end{array}$ & $\begin{array}{l}- \\
-\end{array}$ \\
\hline $\begin{array}{l}\text { Mammary } \\
\text { gland }\end{array}$ & $\begin{array}{l}\bar{x} \\
s \\
\text { CV\% }\end{array}$ & $\begin{array}{r}18.7 \\
5.3 \\
28.3\end{array}$ & $\begin{array}{r}22.2 \\
2.9 \\
13.1\end{array}$ & $\begin{array}{l}- \\
- \\
-\end{array}$ & $\begin{array}{r}77.8 \\
2.5 \\
3.2\end{array}$ \\
\hline
\end{tabular}

$\left.{ }^{1}\right)$ U/g of wet tissue for liver, kidney and mammary gland and $\mathrm{U} / \mathrm{g}$ of hemoglobin for erythrocytes.

Comparison of the pherograms of arginase with a pherogram of serum proteins (fig. $1 \mathrm{~B}$ ) shows that the fastest anodic isoenzyme $A_{1}$ is located between the albumin and $\alpha_{1}$-globulins; $A_{2}$ migrates slower, together with $\alpha_{2}$-globulins, and the cathodic isoenzyme $A_{3}$ has a mobility corresponding to those of $\gamma$-globulins.

All the three isoenzymes are sensitive to ornithine, a well known inhibitor of the arginase activity (13), but to a different degree (fig. 2). Isoenzyme $A_{1}$ is reduced by this amino acid to about $50 \%, A_{2}$ to $10 \%$ and $A_{3}$ to $30 \%$ of the original activity.

Therefore ornithine exerts the greatest inhibitory effect on the kidney enzyme, a slightly smaller effect on the liver and erythrocyte enzyme, while the mammary arginase is the most resistant to this inhibition.

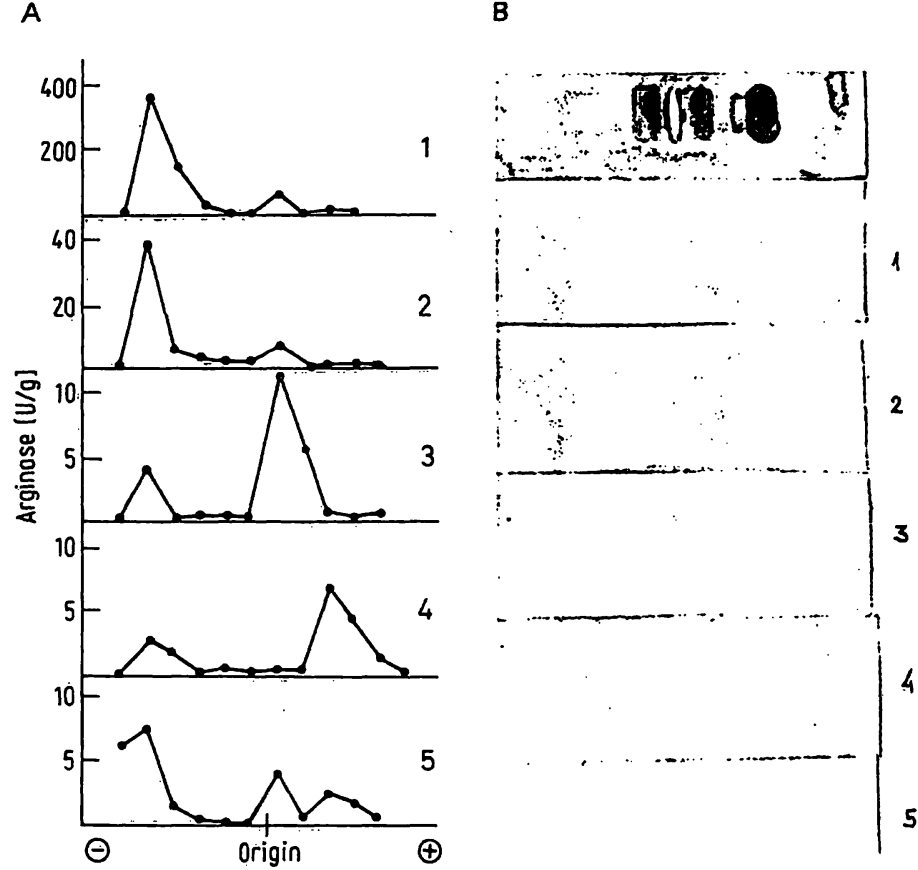

Fig. 1. Human arginase isoenżymes separated by agar gel electrophoresis.

1. liver, 2. erythrocytes, 3. kidney, 4. mammary gland isoenzymes and 5. the pattern of their mixture

A/ the pattern of arginase isoenzymes obtained by elution of the gel strips and determination of urea

$\mathrm{U} / \mathrm{g}$ of wet tissue for liver, kidney and mammary gland, $\mathrm{U} / \mathrm{g}$ of hemoglobin for erythrocytes

$B /$ the pattern of arginase isoenzymes stained by ninhydrin reaction.
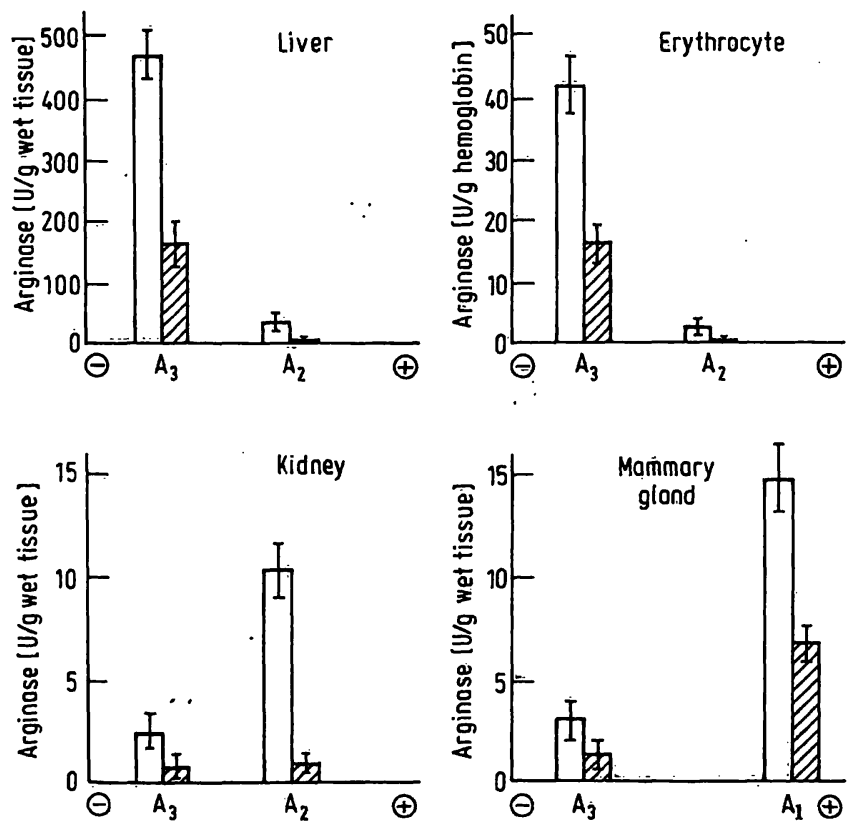

Fig. 2. Inhibitory effect of ornithine in electrophoretically separated arginase isoenzymes.

$\square$ total activity, activity in the presence of ornithine. The column heights and vertical bars represent $\bar{x}$ and $s$ $(n=6)$. 


\section{Discussion}

The results obtained show that arginases of human tissues may be differentiated by their electrophoretic mobilities in agar gel. The finding of two liver isoenzymes is in accordance with the results of Bascur et al (6) who separated the human liver arginase into two fractions on CM-cellulose. The stronger fraction contained 90-95\% and the smaller $5-10 \%$, of the total arginase activity, which is in accordance with the relative activities that we obtained electrophoretically. The same isoenzymic distribution that we found in the liver and erythrocytes confirm the findings of Cabello et al (14) who investigated the stability, $\mathrm{pH}$ curves, $K_{\mathrm{m}}$ and the energy of activation of the liver and erythrocyte arginase, and found a close similarity. A great similarity was demonstrated by immunochemical methods, but complete identity could not be proved (3). Kalab \& Pelikan separated six isoenzymes by electrophoresis using a large sample volume of hemolysate in the agar gel block
(8). They found the bulk of arginase activity in the cathodic isoenzyme, which corresponds to our isoenzyme $A_{3}$.

Using chromatography on DEAE-cellulose Porembska et al (7) found two fractions of arginase activity in the human liver and kidney. While the greater part of liver arginase was bound to the ion exchanger and then eluted with the ionic strength gradient, the bulk of the kidney arginase passed througin the column and only a minor fraction was bound. This is in accordance with our finding of the same two isoenzymes in these two organs but in reverse proportions. Two isoenzymes of the mammary gland arginase have also been found by other authors using electrophoresis in starch gel (4) and gel filtrations (5). The minor peak obtained by gel filtration was in the same fraction as the peak of liver arginase which confirms our finding of the relative minor portion of the $A_{3}$ isoenzyme in the mammary gland.

\section{References}

1. Roberts, E. (1948), J. Biol. Chem.176, 213-222.

2. Folley, S. J. \& Greenbaum, P. L. (1948), Biochem. J. 43, 537-549.

3. Cabello, J., Prajoux, V. \& Plaza, M. (1965), Biochim. Biophys. Acta 105, 583-593.

4. Farron, F. (1973), Anal. Biochem. 53, 264-268.

5. Glass, R. D. \& Knox, W. E. (1973), J. Biol. Chem. 248, 5783-5789.

6. Bascur, L., Cabello, J., Veliz, M. \& Gonzales, A. (1966), Biochim. Biophys. Acta 128, 149-154.

7. Porembska, Z., Baranczyk, A. \& Jachimowicz, J. (1971), Acta Biochim. Pol. 18, 77-85.

8. Kalab, M. \& Pelikan, V. (1966), Acta Univ. Palackianae Olomuc. Fac. Med. 42, 21-29.

9. Jergović, I., Žužić, I., Fǐ̌er-Herman, M. \& Štraus, B. (1970), Clin. Chim. Acta 30, 765-774.

10. Wieme, R. J. (1966), Clin. Chim. Acta 13, 138-139.

11. Chinard, F. P. (1952), J. Biol. Chem. 199, 91-95.

12. Roman, W. \& Ruys, J. (1970), Abstracts of VIIth International congress of Clinical Chemistry, 2, 121.

13. Hunter, A. \& Downs, C. (1945), J. Biol. Chem. 157, 427-446.

14. Cabello, J., Basilio, C. \& Prajoux, V. (1961), Biochim. Biophys. Acta $48,148-152$.
Prof. Dr. B. Štraus Mr. Olga Boř́ić Institute of Medical Biochemistry Domagojeva 2

YU-41000 Zagreb 
